\title{
Three centuries of Slovakian drought dynamics
}

\author{
U. Büntgen · R. Brázdil · D. Frank · \\ J. Esper
}

Received: 26 November 2008/Accepted: 23 March 2009/Published online: 12 April 2009

(C) Springer-Verlag 2009

\begin{abstract}
Tree-ring data from Slovakia are used to reconstruct decadal-scale fluctuations of the self-calibrated Palmer Drought Severity Index (scPDSI) over 1744-2006. The ring width chronology correlates at 0.58 (annual) and 0.88 (decadal) with regional-scale $\left(48-50^{\circ} \mathrm{N}\right.$ and $\left.18-20^{\circ} \mathrm{E}\right)$ summer (June-August) scPDSI variations (1901-2002). Driest and wettest years common to the tree-ring and target data are 1947, 1948, 1964, and 1916, 1927, 1938, 1941, respectively. The model indicates decadal-scale drought 1780-1810, 1850-1870, 1940-1960, and during the late twentieth century. The wettest period occurred $\sim 1745-$ 1775. Instrumental measurements and documentary evidence allow the reconstructed drought extremes to be verified and also provide additional insights on associated synoptic drivers and socioeconomic impacts. Comparison of anomalous dry conditions with European-scale fields of $500 \mathrm{hPa}$ geopotential height retains positive pressure anomalies centered over Central Europe leading to atmospheric stability, subsidence and dry conditions. Negative mid-tropospheric geopotential height anomalies over Western Europe are connected with anomalous wet conditions over Slovakia. Nine existing, annually resolved hydroclimatic reconstructions from Central Europe, which were herein considered for comparison with the Slovakian findings, reveal significant high- to low-frequency coherency among the majority of records. Differences between the
\end{abstract}

U. Büntgen $(\bowtie) \cdot$ D. Frank $\cdot$ J. Esper Swiss Federal Research Institute WSL, 8903 Birmensdorf, Switzerland e-mail: buentgen@wsl.ch

R. Brázdil

Institute of Geography, Masaryk University,

61137 Brno, Czech Republic
Slovakian and the other reconstructions are most evident at the end of the nineteenth century.

Keywords Tree-ring width · Documentary evidence · Drought $\cdot$ Synoptic pattern

$\begin{array}{ll}\text { Abbreviations } \\ \text { CE } & \text { Coefficient of efficiency } \\ \text { CRU } & \text { Climatic Research Unit } \\ \text { DW } & \text { Durbin-Watson } \\ \text { EPS } & \text { Expressed Population Signal } \\ \text { GCM } & \text { Global circulation model } \\ \text { GISS } & \text { Goddard Institute for Space Studies } \\ \text { JJA } & \text { June-August } \\ \text { m asl } & \text { Meter above sea-level } \\ \text { MTM } & \text { Multi-Taper method } \\ \text { PDSI } & \text { Palmer drought severity index } \\ r & \text { Pearson's correlation coefficient } \\ \text { Rbar } & \text { Inter-series correlation } \\ \text { RE } & \text { Reduction of error } \\ \text { scPDSI } & \text { Self-calibrated Palmer drought severity index } \\ \text { STDEV } & \text { Standard deviation } \\ \text { TRW } & \text { Tree-ring width }\end{array}$

\section{Introduction}

The past, present, and projected rates of regional to global temperature change have been extensively investigated by proxy reconstructions, instrumental measurements, and model simulations (IPCC 2007).

In contrast, only little is known about past changes in precipitation regimes (Seager et al. 2007), and modifications of the hydrological cycle in a warming world 
(Huntington 2006). This deficit results from the more regional nature of precipitation variability and the indirect connectivity to changes in external forcing. Future trends in return period and intensity of precipitation extremes, regional heat waves and related drought spells are also more poorly understood (Pauling and Paeth 2007). Estimates of related eco-physiological (e.g., biomass productivity, species composition, carbon cycle), and socio-economic (e.g., water quality and quantity, crop yields, insurance costs) consequences remain insecure in the context of global change.

For Central Europe, efforts have recently been made in assessing instrumental-based precipitation and drought fluctuations of the past two centuries (see references herein). Long-term estimates of monthly to annually resolved hydro-climatic variations are based on documentary evidences (Brázdil et al. 2005 and references therein), tree-ring chronologies (Brázdil et al. 2002; Oberhuber and Kofler 2002; Wilson et al. 2005), or multi-proxy compilations (Casty et al. 2005; Pauling et al. 2006). Pronounced differences of regional precipitation variability, however, restrict research strategies to rather small areas, with continental-scale comparison and interpretation remaining challenging (Raible et al. 2006).

Here we focus on the highly valuable agricultural area of the Central European Carpathian basin from where systematic and continuous meteorological observations reach back to 1851 . For Slovakia in particular, monthly precipitation totals were developed back to 1881 (Šamaj and Valovič 1982), with their trends and variability (Lapin and Faško 1996, 1998; Cebulak et al. 2000) being accompanied by PDSI data (Klementová and Litschmann 2002; Litschmann and Klementová 2004) over the 18762003 period. Moreover, Brázdil and Kiss (2001) utilized visual daily weather records from Košice for the period 1677-1681, and Brázdil et al. (2008a) compiled early instrumental observations from Prešov with other documentary archives from eastern Slovakia for 1717-1730. Precipitation indices based on documentary data covering the entire Carpathian basin and spanning the eighteenth (Réthly 1970) and nineteenth century (Réthly and Simon 1998-1999) were used for reconstruction purposes (Rácz 1999), climatologically explored (Bartholy et al. 2004), and analyzed with respect to trends in temperature and precipitation extremes (Bartholy and Pongrácz 2007).

This study presents the first tree ring-based reconstruction of Slovakian summer drought variability over almost the past three centuries, which is compared and assessed in the light of existing instrumental, documentary, and proxy records available for Central Europe.

\section{Data and methods}

\subsection{Tree-ring data and detrending}

Cores from 86 pine (Pinus sylvestris) trees were collected in November 2006. The sampling site $(\sim 800 \mathrm{~m}$ asl, $48.55^{\circ} \mathrm{N}$ and $20.17^{\circ} \mathrm{E}$ ) is located in steep rocky (limestone) terrain $\sim 15 \mathrm{~km}$ south of Poprad (Slovakia) between the High Tatra Mountains in the north and the Low Tatra Mountains in the west, southwest. Mean segment length constantly decreases towards present, whereas mean tree age increases (Fig. 1). Less than 5 (10) series extend prior to 1744 (1753). Mean segment length is 181 years and ranges from 33 to 273 years. Average growth rate is $0.695 \mathrm{~mm} /$ year. Estimated pith-offset for each core sample ranges from 0 to 80 years, with a mean of 13 years, and 59 values $\leq 10$ years.

According to standard procedures, tree-ring width (TRW) measurements were performed on all cores. Resulting series were cross-dated and any dating errors corrected before removing non-climatic, tree-age related growth trends (Fritts 1976). For the preservation of interannual to multi-decadal scale variability, TRW series were individually detrended by calculating ratios from cubic smoothing splines with $50 \%$ frequency-response cutoff equal 150 years (Cook and Peters 1981). The resulting TRW chronology was calculated using a bi-weight robust mean (Cook 1985), and variance was stabilized using the MEANr correction as in Frank et al. (2007b). The interseries correlation (Rbar) and the Expressed Population Signal (EPS), both computed over 30 years lagged by 15 years, were used to estimate common variance and signal strength of the final record (Wigley et al. 1984).
Fig. 1 Temporal distribution of the Slovakian TRW compilation with grey bars representing the 86 individual measurement series and black bars indicating the corresponding pith-offset estimations

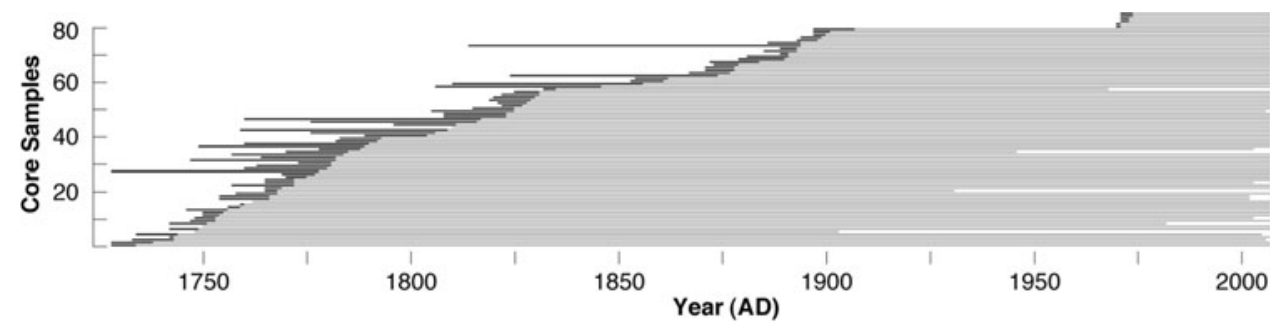




\subsection{Instrumental and documentary data}

For growth-climate response analyses, monthly temperature means, precipitation totals (CRUTS2.1; Mitchell and Jones 2005), and the self-calibrated Palmer Drought Severity Index (scPDSI; van der Schrier et al. 2006) were used. These data are freely available (http://www.cru.uea. ac.uk) and most likely represent the best source of different, well-homogenized climatic parameters for the region. The scPDSI is a modification of the original measure of regional moisture availability that better allows comparison of drought from different regions, however, does not take snow melting into account (van der Schrier 2008, personal communication). For calculation of the water holding capacity, Goddard Institute for Space Studies (GISS) 'texture'-based $1^{\circ}$ grid-box data were used, with a value of $480 \mathrm{~mm}$ corresponding to our study region. Data were selected from a $0.5^{\circ}$ grid-box centered over $48.25^{\circ} \mathrm{N}$ and $20.25^{\circ} \mathrm{E}$, covering the period $1901-2002$, and representing a mean elevation of $279 \mathrm{~m}$ asl. Therefore, all climatic data were transformed to anomalies with respect to the 1961-1990 period. Inter-annual to decadal-scale variability in regional summer climate is summarized in Fig. 2. A hydro-climatic separation of the twentieth century appears to be most important and distinguishes between wetter and drier conditions over the earlier and later half, respectively. The inverse relationship between summer temperature and precipitation (see references herein), and both their influences on the drought metric prevent the three climatic parameters from being independent (Fig. 2). Lag-1 autocorrelations of the temperature, precipitation, and scPDSI records are 0.37, 0.10, and 0.44 (1901-2002). Lag-1 autocorrelation of the TRW chronology (0.44) is similar to that of the drought data.

Proxy/instrumental correlations were computed for 21 months from April of the previous year to December after ring formation, and 28 seasonal means including various combinations of monthly March-October values of the growing season. Average correlation (1901-2002) between the 28 seasonal scPDSI targets is 0.93 , ranging from 0.63 (March-April vs. September-October) to 0.99 (March-September vs. March-October), resulting from highly inter-correlated monthly PDSI data and their overlap. To assess temporal changes in the obtained growth/ climate relationships, two split periods were defined (1901-1951/1952-2002). We then scaled the mean and
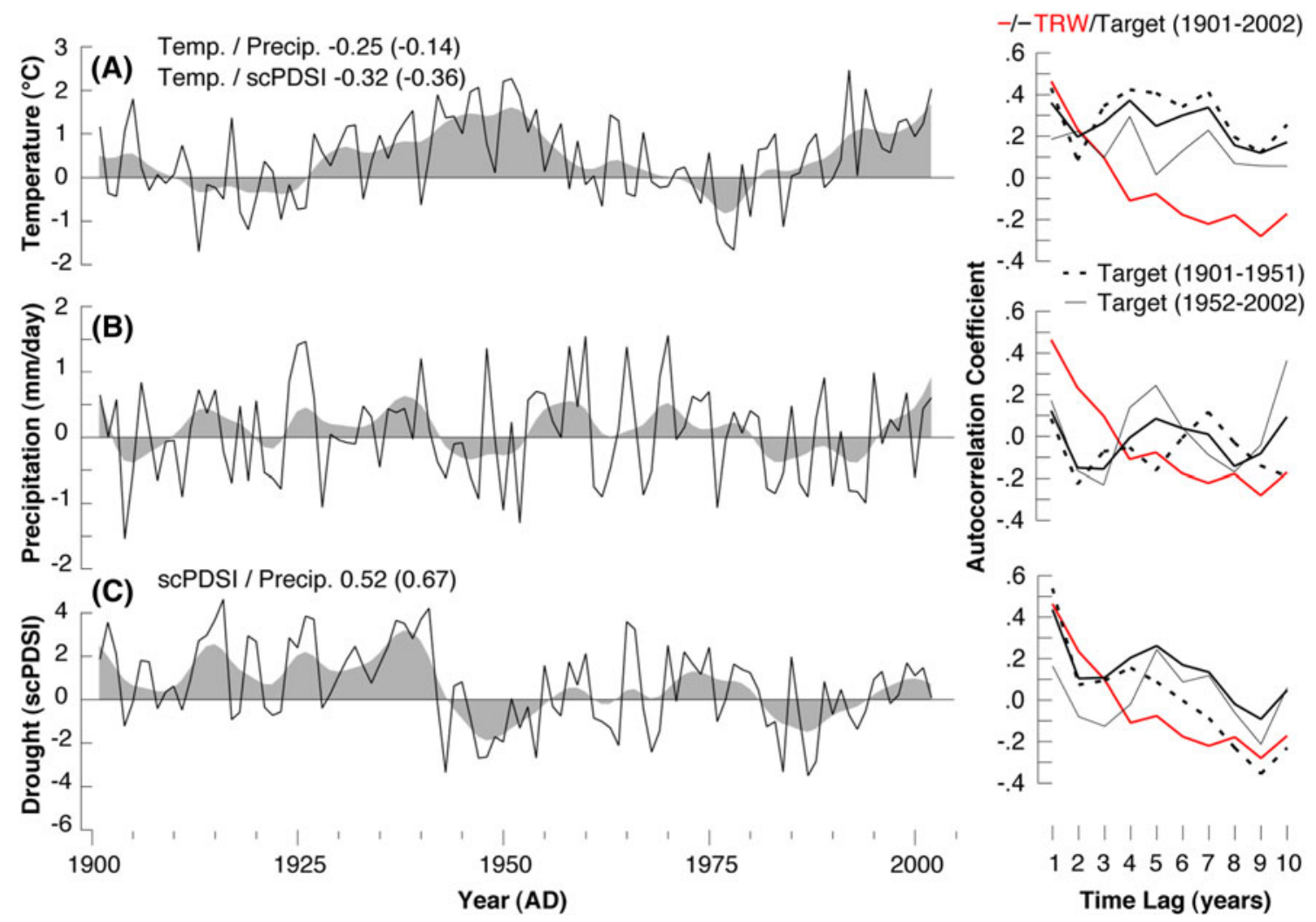

Fig. 2 Regional-scale variability of June-August a temperature, b precipitation, and c scPDSI anomalies with respect to the 1961-1990 mean. Grey shadings denote decadal-scale variability after 10 year low-pass filtering. Inter-parameter correlations were computed over 1901-2002 and brackets refer to the low-passed time-series. Right- hand side shows autocorrelation structure of the target temperature, precipitation and scPDSI data (black) compared to the proxy TRW chronology (red) computed over the full (bold), and two early/late split periods (dashed/thin) 
variance of the tree-ring proxy to those of the drought target over the full period of overlap to reconstruct summer scPDSI over the 1744-2006 interval. Calibration/verification trials of two split periods were performed using the Pearson's correlation coefficient $(r)$, reduction of error (RE), coefficient of efficiency (CE), and Durbin-Watson (DW) statistics (Cook et al. 1994; Durbin and Watson 1951)

In addition to the commonly applied verification statistics introduced, comparison between the tree-ring model and documentary evidence allowed independent verification of the reconstructed most extreme (dry and wet) summers. Seasonal precipitation totals of Slovakia (Šamaj and Valovič 1982) were calculated for spells occurring after 1881. Extreme summers before 1881 were evaluated with respect to documentary data available for Slovakia and/or surrounding countries such as the Czech Lands (Dobrovolný et al. 2009) or eastern Austria (Strömmer 2003). Information from Slovakia and the Carpathian basin was taken exclusively from Réthly (1970) for the eighteenth century, and from Réthly and Simon (1998-1999) for the nineteenth century. These documentary sources can reflect periods of dry, hot or warm weather. In addition, drought impacts on agricultural production such as poor hay, crop, and fruit harvests with a consequent lack of food for people and fodder for animals are reported. Fires, low water levels in rivers, water mills out of operation, and early grape harvest or sweet grapes are other indicators of dry weather. In contrast, wet conditions may be reflected via entries of rainy spells, flood occurrences, late or bad courses of harvest works, late grape harvests and sour wine.

Moreover, nine annually resolved reconstructions of spring/summer precipitation from Central Europe were aggregated to allow their hydro-climatic history to be compared (see Table 3 for details and abbreviations). Seven reconstructions are based on TRW measurements, two combine documentary and instrumental data (PFI and $G L A$ ), and one is a multi-proxy (instrumental data, treering chronologies, documentary archives) approach (PAU; using grid-boxes between $48-49^{\circ} \mathrm{N}$ and $20-21^{\circ} \mathrm{E}$ ).

\section{Results}

\subsection{Climate sensitivity}

The TRW chronology correlates positively $(r>0.5)$ with monthly scPDSI values of May through September, and seasonal means between March and October. Highest correlation of 0.58 is found with June-August scPDSI data. Previous year drought effects are non-significant. Negative (though non-significant) correlations are derived from the various temperature means, whereas positive correlations (ranging below those found with the scPDSI) are evident for summer precipitation. Overall highest correlations are obtained with summer scPDSI.

Frequency-dependent summer June-August (JJA) drought sensitivity of the TRW chronology is indicated by unfiltered, low-, high- and band-pass filtered data (using the full and two early/late split periods). The unfiltered records correlate at 0.58 with stronger agreement over the early (0.74) than late $(0.45)$ period. After 10 year low-pass filtering, correlations are systematically higher in comparison to those obtained from the unfiltered data, ranging from 0.57 to 0.82 computed over the late and early period, respectively. Correlation coefficients for the 20-60 year low-passed data and computed over the full period 19012002 are most variable and decrease from 0.60 (after 20 year smoothing) to 0.00 (after 60 year smoothing). These values change to $0.60-0.92$ and $0.61-0.78$ when computed over the early and late period, respectively. In comparison, a more structured picture is seen in the highpass filtered data. Correlations after 10-60 year high-pass filtering constantly increase from 0.56 to 0.62 when computed over the full period 1901-2002. Generally higher correlations (0.67-0.75) derive from the early 1901-1951 period, whereas lower correlations (0.39-0.44) are gained from the second half of the twentieth century. Substantial differences are also obtained after band-pass filtering. While correlations from the early period are constantly above 0.77 , correlations from the late period increase from 0.38 to 0.89 (10-20 and 40-50 year bands). Overall the highest correlations of $\sim 0.88$ are obtained in the 40 50 year frequency domain.

In summary, soil moisture availability is the primary factor limiting pine growth at this cliff site. Radial growth best reflects June-August soil water content, emphasized by an inverse growth response to warm season temperature, and positive relationships with precipitation. Caution is advised, as the series analyzed are highly auto-correlated.

\subsection{Reconstruction skill}

To avoid regression-based variance reduction in the model, the 150 year spline chronology was scaled to twentieth century JJA scPDSI indices (Fig. 3b). Correlation between the predictor and predictand over the full 1901-2002 period of overlap is 0.58 and increases to 0.74 over the first half, but decreases to 0.45 over the second half of the century. Proxy and target time-series portray common inter-annual to decadal scale variability. Quasi-periodic fluctuations of dry (i.e., 1905, 1920, 1935) and wet (i.e., $\sim 1915$, 1925, 1938) modes are most evident during the first half of the twentieth century, for which both records reflect generally wetter conditions compared to the second half of the century. The severe summer drought spell in the 

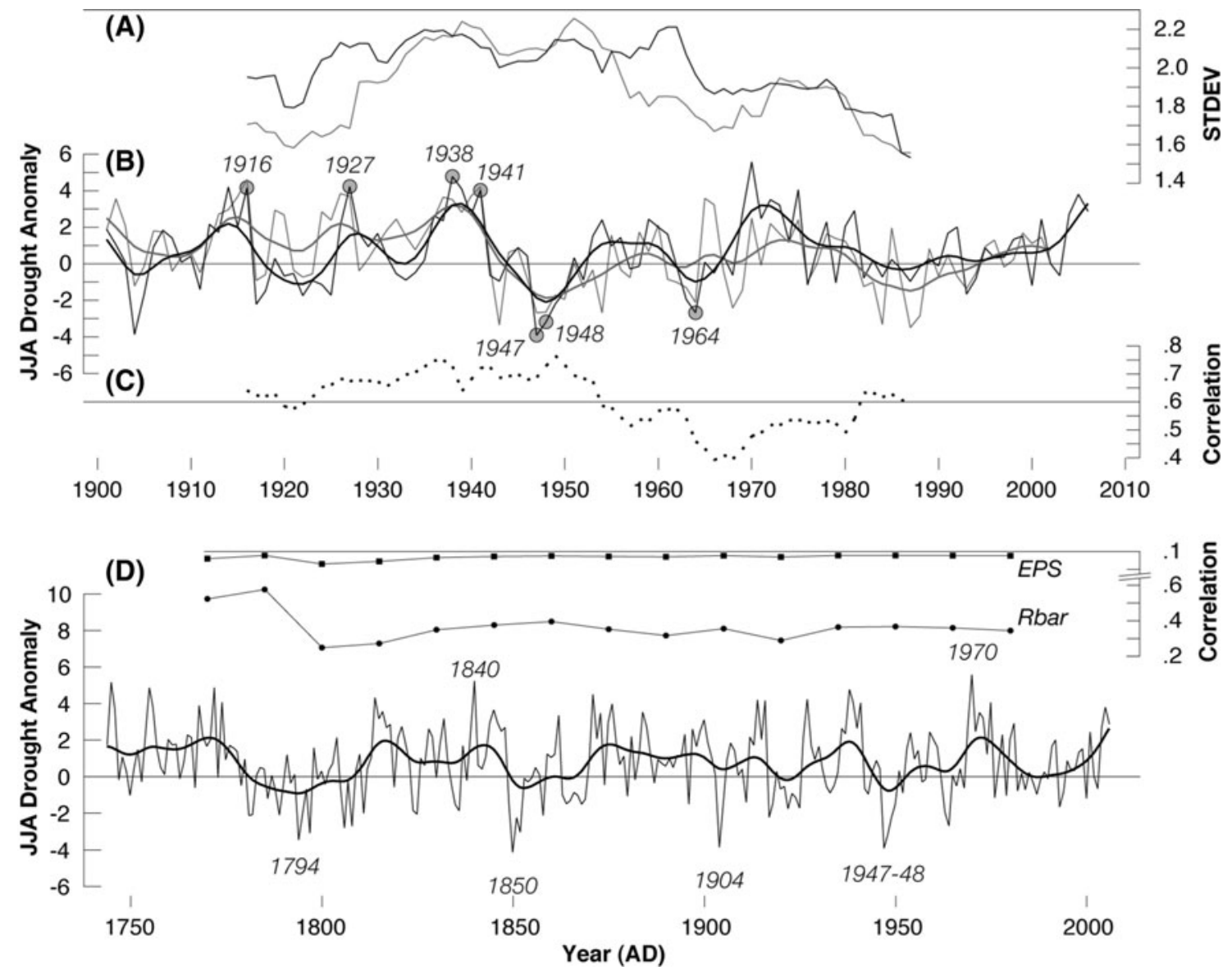

Fig. 3 a 31 year moving STDEV of $\mathbf{b}$ the 150 year spline chronology (black) scaled over 1901-2002 to June-August scPDSI data (grey), their 10 year low-pass filters, and c 31 year moving correlations. Droughts are expressed as anomalies with respect to the 19611990 mean. Circles denote those year that range within the ten most extremes common to proxy and target data (1901-2002).

1940s is followed by a shift towards generally drier conditions until the late 1960s. Wetter summers are again recorded during the 1970 s, and a decadal-long negative anomaly centered $\sim 1985$ indicates relatively dry conditions, followed by more pluvial summer conditions until present. Decadal-scale fluctuations are emphasized via smoothing functions, but potential longer-term trends are not preserved by our reconstruction (Fig. 3).

Moving 31 year standard deviations (STDEV) of the proxy and target data reveal variance changes common to
Reconstructed driest and wettest years are 1947 and 1970, whereas the measured extremes are 1987 and 1916, respectively. d The new JJA scPDSI estimate (black plus 20 year low-pass filter) back to 1744. Rbar and EPS statistics additionally indicate the robust signal strength of the TRW-based chronology

both records (Fig. 3a). While increased variance is evident from $\sim 1930$ to 1955 , decreasing variance is found near the records' end, with lowest inter-annual to decadal-scale variability being observed towards present. Moving 31 year correlations between TRW and scPDSI data specify a shift from higher to lower coherency around the mid-century (Fig. 3c), in line with the calibration/verification results summarized in Table 1 . The overall significant $(P<0.05)$ moving window correlations between the proxy and target data range from $\sim 0.40$ to 0.77 and show a decline during

Table 1 Calibration/verification statistics of the 150 year spline TRW chronology and June-August scPDSI data. RE and CE statistics refer to the regression model. Methodological explanation of the DW, RE, and CE values is given in the text

\begin{tabular}{|c|c|c|c|c|c|c|c|}
\hline \multirow[b]{2}{*}{ Period } & \multicolumn{5}{|c|}{ Calibration } & \multicolumn{2}{|c|}{ Verification } \\
\hline & Spline & $r$ (original) & $r(10$ year high-passed $)$ & $r$ (10 year low-passed) & DW & $\mathrm{RE}$ & $\mathrm{CE}$ \\
\hline $1901-1951$ & 150sp & 0.74 & 0.67 & 0.82 & 1.26 & 0.10 & -0.24 \\
\hline 1952-2002 & 150sp & 0.45 & 0.44 & 0.58 & 1.54 & 0.22 & 0.01 \\
\hline 1901-2002 & 150sp & 0.58 & 0.57 & 0.62 & 1.22 & & \\
\hline
\end{tabular}


the 1940-1960s, followed by an increase towards present. Annual residuals between the modeled and actual values indicate an overall increase throughout the twentieth century, with lowest $(<-4.0)$ and highest $(>4.0)$ values in 1924-1925 and 1954, 1969, respectively (not shown). This finding, together with the DW, RE and CE statistics demonstrates potential low-frequency offset between the proxy and target time-series (Table 1).

Comparison between the original (unfiltered) and smoothed (10 year low-pass filtered) data shows higher correlations on decadal-scales, independent of the calculation period used. In contrast, overall lowest correlations are obtained after 10 year high-pass filtering. Positive DW statistics as obtained from the full, early and late periods $(1.22,1.26$ and 1.54) all indicate some first order autocorrelation in the model residuals. While positive RE verification statistics refer to some skill in the model, CE values range from 0.00 to -0.24 . With respect to the time window, one must note the somewhat lower calibration/verification statistics for the 1952-2002 period (Table 1). During this latter period, lower correlation of the original, high- and low-passed time-series suggest temporal instability in the proxy/target relationship. Similar weakening during the most recent modeling period was reported for southern Moravia (Brázdil et al. 2002), and Bavaria (Wilson et al. 2005). Due to the relatively short period of reliable instrumental readings (e.g., Mitchell and Jones 2005), the twentieth century drought data are not long enough to robustly test for significant temporal differences in the relationship with the new Slovakian record. More tree-ring proxy (and instrumental target) data from this region are needed to confirm any systematic disturbances in the post-1970s relationship between tree growth and climate forcing (Büntgen et al. 2008).

The preservation of long-term trends in our study is limited by the given tree-age structure of the dataset and the tree-ring detrending applied. The reconstructed decadal-scale drought variability, however, is in line with European-wide twentieth century scPDSI grid data (van der Schrier et al. 2006). Substantial deviations below and above the long-term mean (0.76) include $\sim 1790$, 1860, 1950, 1990 and $\sim 1760,1830,1880,1940,1970$, respectively. Alternating dry and wet episodes tend to be longer before 1900 and shorter afterwards. Very dry conditions were most severe in 1794, 1850, 1904, and 1947. Considering instrumental observations of the twentieth century and averaged over the European continent (van der Schrier et al. 2006), the wettest summer was 1915 and the driest summer was 1947. The new Slovakian proxy also reconstructed 1947 to be the driest summer, but indicates 1914 and 1916 as the forth and fifth wettest years from 1901 to present, while the summer of 1915 was not identified as extremely wet. According to the tree-ring proxy, 1970 was the wettest summer of the last century. In summary, the TRW record tracks JJA scPDSI variations reasonably well although there is a weakening in coherency during the later half of the calibration. Enhanced agreement, however, is found during the first half of the model period. Four periods of severe droughts are centered $\sim 1790,1860,1950$, and 1990.

Additional time-series analysis using the Multi-Taper method (MTM; Mann and Lees 1996) reveals reasonable inter-annual to decadal scale coherency of the modeled and measured JJA scPDSI power spectra (Fig. 4a). Common peaks are found at $\sim 2.6,3.4$, and 5-6 years. Disagreement is most obvious in the lower frequency domain, since the TRW data indicate significant periodicity $\sim 12-17$ years, but the target data contain enhanced variability $>34$ years. Such lower frequency offset might be related to the treering detrending methods used and the homogenization applied to the instrumental measurements (see Frank et al. 2007a for details). The spectrum computed over the full 1744-2006 reconstruction period reveals the most significant $(P<0.1)$ power peak $\sim 15$ years (Fig. $4 b)$. Significant periodicity is further indicated at $\sim 7.5,5.8$, and $\sim 2.7$ years. Similar power peaks $(P=0.05)$ on interannual and decadal time-scales were recognized in the shorter 1881-2006 JJA scPDSI series of the Czech Republic (Brázdil et al. 2008b). Temporal characteristic of the different cycles is addressed using wavelet analysis (Torrence and Compo 1998), and illustrated in Fig. 4c. The wavelet indicates significant power at $\sim 15$ years for two periods centered $\sim 1850$ and $\sim 1950$. In contrast, significant (though less robust) power at $\sim 60$ years is detected from $\sim 1750$ to 1850 , but not afterwards. These findings are confirmed by the MTM spectra.

Spatial analysis using field correlations between this study and gridded drought data retains apparent boundaries and gradients of explained drought variability (Fig. 5a). The TRW proxy correlates $>0.6$ with JJA scPDSI grid-box data (1901-1978) only in a small area south of its origin in southern Slovakia and northern Hungary. In contrast, spatial field correlations between the summer temperature reconstruction from the Tatra Mountains (Büntgen et al. 2007) and gridded temperature data reveal correlations $>0.6$ across most of the Balkan Peninsula, east Italy and Moldavia (Fig. 5b). Spatial correlation patterns of the drought and temperature reconstructions to their corresponding grid-box targets denote parameter-specific differences in European-scale climate variability. Smaller areas of explained drought variance suggest that a greater amount and more widespread distribution of predictors would be needed to reconstruct Central European drought in comparison to temperature. 

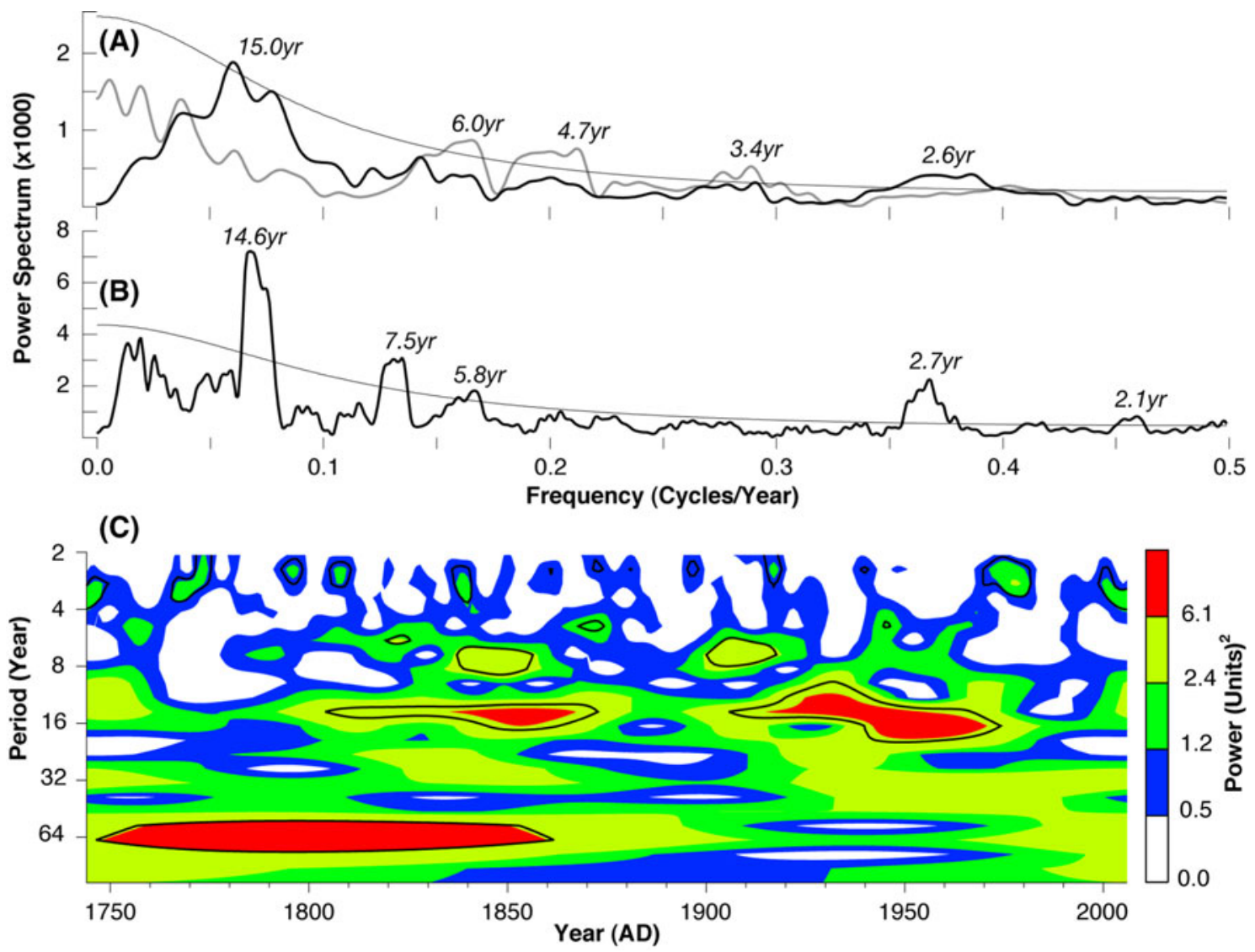

Fig. 4 a MTM spectra using 2 year resolution/three tapers of the 150 year spline chronology (black) scaled against JJA scPDSI data (grey) calculated over 1901-2002, and b the new drought reconstruction (1744-2006). Thin lines are 90\% confidence limits. c Wavelet (Morlet 6.0/6) power spectrum of the reconstruction (1744-

\subsection{Documentary evaluation}

Linkage between the 20 most extreme negative (dry) and positive (wet) years of the new JJA scPDSI reconstruction (with respect to the 1961-1990 mean) and instrumental/ documentary data is shown in Table 2. For most of the events, precise information on spatial extent and prevailing climate condition is indicated. Due to the specific character of documentary evidence and the fact that systematic historical climate research is still developing in Slovakia (e.g., Brázdil and Kiss 2001; Brázdil et al. 2008a), the selected extremes before the instrumental period are not always comparable in the same manner (Table 2). Noteworthy is a doubled number of negative scPDSI extremes during the nineteenth century compared to the amount of positive departures. Positive extremes are slightly more frequent during the eighteenth and twentieth centuries. Extreme dry summer anomalies are found during 1781-1782, 17941795 (1797), 1850-1852, and 1947-1949. As for the latter case, all seasons were significantly below the corresponding average in 1947, whereas only March-May and
2006), with contour levels chosen to be at $75,50,25$, and $5 \%$ of the wavelet power above each level. Black contour is the $10 \%$ significance level using a red-noise (autoregressive lag-1) background spectrum

September-November was exceptionally dry in 1948, and only the winter in 1949 was below average. The corresponding dry episode reported for the Czech Republic and based on monthly scPDSI lasted from April 1947 to June 1954 (Brázdil et al. 2008b). No summer during the late1980s to early-1990s appeared to be within the 20 most extreme summers, an absence most likely due to the relatively low temperatures. Even though, the recent warmth became evident after the early 1990s (see Fig. 3 for comparison), the lowest scPDSI value for the Czech Republic since 1881 occurred between April 1988 and December 1994 (Brázdil et al. 2008b). No fingerprint of the outstanding 2003 European summer heat (Schär et al. 2004) was found in the new Slovakian tree-ring proxy. For details on the intensity, duration, and spatial extent of this exceptional spell in Slovakia, we refer to Faško et al. (2003), and Klementová and Litschmann (2004). Distinct sequences of positive (wet) extremes as reconstructed for Slovakia occurred in 1745-1746, 1755-1756, 1938-1939, and 1941 (Table 2). Moreover, a break of only one 'regular' year has been noted between the extreme summers of 


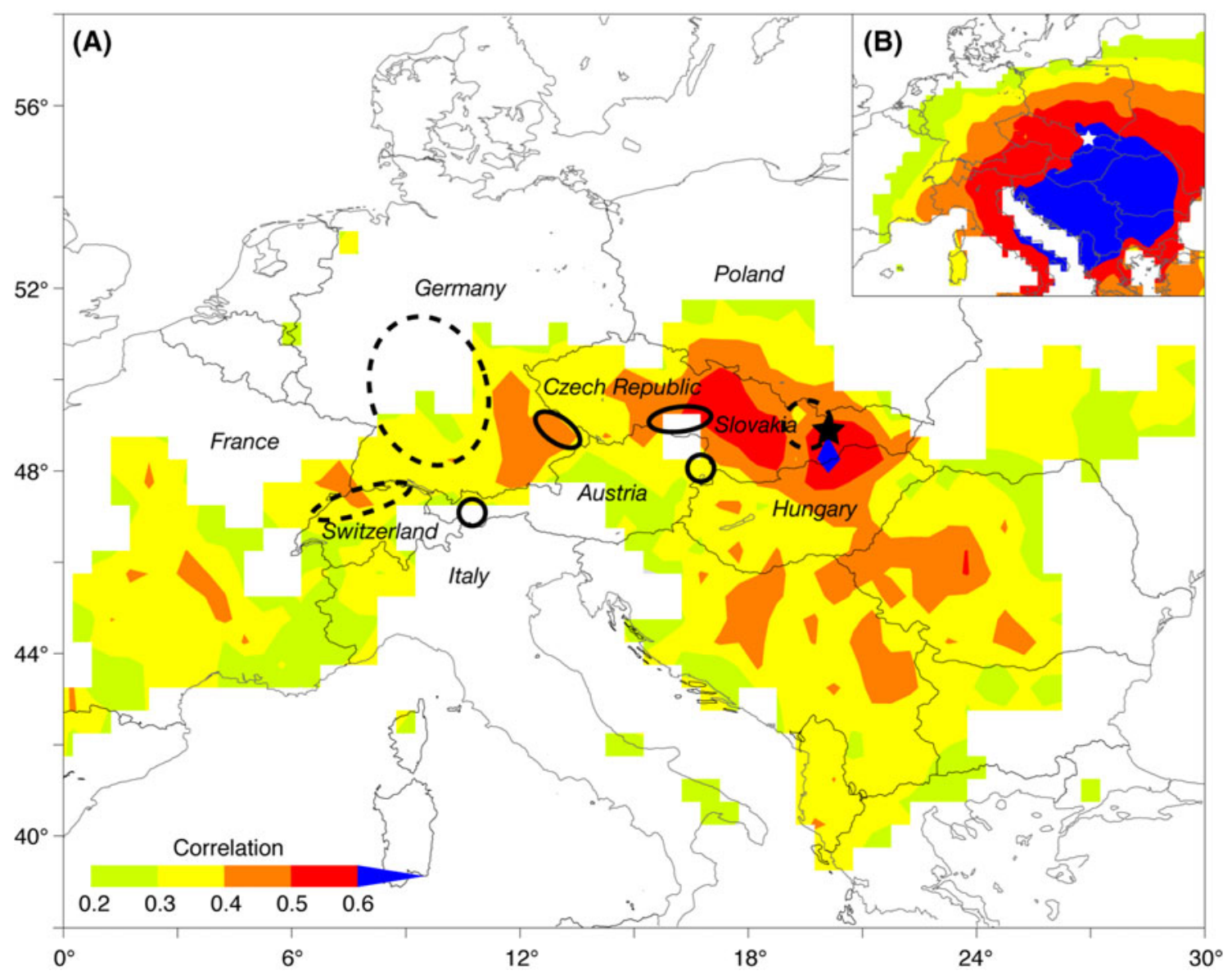

Fig. 5 a Spatial field correlation of the new Slovakian record (black star) against JJA drought data $\left(0.5 \times 0.5^{\circ}\right.$ scPDSI grid-boxes $)$ computed over the 1901-1978 period. Circles indicate locations of the ten hydro-climatic records used for comparison. Dashed lines

1772 and 1774, as well as 1914 and 1916. In such peculiar cases, totals of March-May and June-August precipitation over Slovakia were above the meteorological long-term mean, whereas precipitation sums of the previous winter were either below or above those usually recorded for December-February.

With respect to the climatic interpretation of such consecutive extreme years, caution is advised, as the second event could potentially reflect integrative climate effects from the previous year upon radial ring formation (Frank et al. 2007a). Such autocorrelation most likely results from the paucity of carbohydrates stored towards the end or even after the growing season, or from longer-term benefits (or detriments) in mobilizing resources from root and needle growth following good (or poor) years (Kozlowski and Pallardy 1997). As an example, we refer to the summer of 1746 that was climatologically characterized by a pronounced summer drought across Moravia and eastern Austria, though revealed a fairly high scPDSI value possibly resulting from very wet (favorable) previous summer conditions (see Table 2 for details). indicate studies of less defined regional-scale. b Spatial field correlation of the Tatra summer temperature reconstruction (white star; Büntgen et al. 2007) using $0.5 \times 0.5^{\circ}$ temperature grid-boxes and the 1901-1978 period

\subsection{Synoptic patterns}

Synoptic-scale circulation types were evaluated using reconstructed fields of gridded $500 \mathrm{hPa}$ geopotential heights back to 1659 (Luterbacher et al. 2002). A composite technique revealed the dominant mid-troposphere pressure systems triggering the 26 driest and 26 wettest summers (equal $10 \%$ in both cases) over the period 1744 1999 (Fig. 6). While a maritime-continental pattern of below-average $500 \mathrm{hPa}$ geopotential heights over westernCentral Europe is found to be associated with the most pluvial conditions, a distinct high-pressure cell above central-Eastern Europe induced regional drought extremes. These patterns are in line with previous findings of exceptionally wet and dry spells (monthly precipitation totals $\leq 50 \%$ and $\geq 150 \%$ of the corresponding long-term mean) in Slovakia over 1949-1980 (Brázdil and Štekl 1986). Lows expressed at the $500 \mathrm{hPa}$ level located over France or the Alps were most important for high precipitation totals. Generally higher precipitation totals within 
Table 2 The 20 most negative/positive TRW-based JJA scPDSI values (1744-2006) for Slovakia in comparison with other related sources (seasonal precipitation totals during the instrumental period are expressed in \% of the corresponding 1901-2000 means)

\begin{tabular}{|c|c|c|}
\hline Year & PDSI & Short description of weather or related events and comparison with measurements \\
\hline \multicolumn{3}{|c|}{ Dry spells } \\
\hline 1850 & -4.14 & Czech Lands: very dry in May, Jul, and Aug \\
\hline 1947 & -3.91 & Slovakia-precip: DJF 91.4\%, MAM 61.1\%, JJA $73.9 \%$, SON $84.4 \%$ \\
\hline 1904 & -3.86 & Slovakia-precip: DJF 109.4\%, MAM 80.6\%, JJA $44.0 \%$ \\
\hline 1794 & -3.45 & $\begin{array}{l}\text { Slovakia: great drought in spring and summer, bad harvest, lack of hay, often fires for drought; early sweet grapes (from mid- } \\
\text { Aug); Czech Lands: great drought in spring and summer }\end{array}$ \\
\hline 1948 & -3.21 & Slovakia-precip: DJF 181.3\%, MAM 94.9\%, JJA $115.6 \%$, SON $76.0 \%$ \\
\hline 1797 & -3.08 & Czech Lands: dry between Jul and Sep; eastern Austria: hot and dry in Jul-Aug \\
\hline 1852 & -3.04 & Czech Lands: dry Jul \\
\hline 1806 & -2.80 & Slovakia (Trenčín region): warm and dry May-Jun; Czech Lands: dry in May-Jun; eastern Austria: warm from May to Aug \\
\hline 1808 & -2.70 & $\begin{array}{l}\text { Slovakia (Košice): dry spring with a few rains; Czech Lands: very dry in May, Jul, and Aug; eastern Austria: warm in } \\
\text { May-Jun }\end{array}$ \\
\hline 1964 & -2.69 & Slovakia-precip: DJF 49.6\%, MAM 69.1\%, JJA $104.7 \%$ \\
\hline 1851 & -2.25 & Czech Lands: very dry in May \\
\hline 1917 & -2.22 & Slovakia-precip: DJF $115.1 \%$, MAM $75.4 \%$, JJA $49.4 \%$ \\
\hline 1949 & -2.22 & Slovakia-precip: DJF $68.3 \%$, MAM $107.4 \%$, JJA $118.3 \%$ \\
\hline 1795 & -2.15 & $\begin{array}{l}\text { Slovakia: remembered drought from 1794; Romania: drought in May; Ukraine: drought in Jun; Czech Lands, eastern Austria: } \\
\text { rainy and cold Jul }\end{array}$ \\
\hline 1858 & -2.13 & Czech Lands: drought from spring to harvest time (Jul) \\
\hline 1781 & -2.12 & $\begin{array}{l}\text { Slovakia: drought from mid-Apr; hot and dry summer, bad harvest; in Sep a low water level in Danube; eastern Austria: hot } \\
\text { and dry in Jul-Sep }\end{array}$ \\
\hline 1789 & -2.10 & $\begin{array}{l}\text { Slovakia: often fires in spring due to great drought; dry and warm autumn; lack of food and fodder for cattle; eastern Austria: } \\
\text { great drought in May-Jun }\end{array}$ \\
\hline 1782 & -2.09 & $\begin{array}{l}\text { Slovakia: hot two weeks in Jun, warmth continuing in Jul and Aug; in Aug drought and locusts; on } 20 \text { Sep reported low water } \\
\text { in Danube due to long-term drought; eastern Austria: very dry from Jun to Sep, low water in watercourses }\end{array}$ \\
\hline 1825 & -2.05 & Slovakia: dry and warm April; long-lasting drought before late Jul; Czech Lands: very dry in Jul \\
\hline 1811 & -2.05 & $\begin{array}{l}\text { Slovakia (Bratislava): dry and hot from May to Sep; early harvest/vintage, outstanding quality of wine; Czech Lands: very } \\
\text { dry between May and Sep (Jul extremely dry); eastern Austria: dry and hot from May to Jul; early vintage }\end{array}$ \\
\hline \multicolumn{3}{|c|}{ Wet spells } \\
\hline 1970 & 5.58 & Slovakia-precip: DJF 119.4\%, MAM 110.9\%, JJA 133.9\% \\
\hline 1840 & 5.24 & $\begin{array}{l}\text { Slovakia: floods of the Danube in Bratislava due frequent rains ( } 3 \mathrm{Aug} \text { ); flood of Tisza without exact dating, rains lasting } \\
40 \text { days (Košice) }\end{array}$ \\
\hline 1745 & 5.17 & Czech Lands: very wet in May and extremely wet in Aug; eastern Austria: prevailingly rainy weather in summer \\
\hline 1772 & 4.87 & Czech Lands: variable weather in Feb-Jun; rainy Jun; eastern Austria: rains in May \\
\hline 1755 & 4.86 & Czech Lands: wet in Jun and very wet in Jul; eastern Austria: wet summer \\
\hline 1938 & 4.78 & Slovakia-precip: DJF 111.5\%, MAM 104.0\%, JJA 121.8\% \\
\hline 1871 & 4.50 & Slovakia (Komárno): wet from Apr to Jun (very wet in May); Czech Lands: cold spring; 3 weeks of rain in Jul-Aug \\
\hline 1814 & 4.32 & $\begin{array}{l}\text { Slovakia (Komárno): cold and wet summer and autumn with floods; bad vintage, sour wine; eastern Austria: rain in Jun with } \\
\text { flood of the Danube, continuation of heavy rain in Jul and Aug }\end{array}$ \\
\hline 1927 & 4.23 & Slovakia-precip: DJF 99.3\%, MAM 136.0\%, JJA $123.0 \%$ \\
\hline 1914 & 4.20 & Slovakia-precip: DJF 65.5\%, MAM 121.7\%, JJA 96.9\% \\
\hline 1916 & 4.16 & Slovakia-precip: DJF 151.8\%, MAM 99.4\%, JJA 96.5\% \\
\hline 1939 & 4.09 & Slovakia-precip: DJF 86.3\%, MAM 158.3\%, JJA 100.8\% \\
\hline 1774 & 4.07 & Slovakia: on 19 Jul a flood on the Poprad river; eastern Austria: rainy Jun \\
\hline 1975 & 4.05 & Slovakia-precip: DJF $88.5 \%$, MAM $115.4 \%$, JJA $116.0 \%$ \\
\hline 1941 & 4.03 & Slovakia-precip: DJF $84.2 \%$, MAM $136.0 \%$, JJA $117.1 \%$ \\
\hline 1876 & 3.97 & Czech Lands: downpours in summer with local floods \\
\hline 1768 & 3.89 & Czech Lands: downpours in summer; eastern Austria: rains in Apr and Jul with increase of water level in watercources \\
\hline 2005 & 3.80 & Slovakia-precip: DJF 118.7\%, MAM 103.4\%, JJA 126.5\% \\
\hline 1756 & 3.80 & Moravia: very wet Aug; eastern Austria: cold Aug and rains in Sep; bad vintage and more sour wine due to rains \\
\hline 1746 & 3.72 & $\begin{array}{l}\text { Hungary: wet autumn; Moravia: great drought from Apr to Sep; eastern Austria: great drought from Apr to Sep, less water in } \\
\text { watercourses }\end{array}$ \\
\hline
\end{tabular}




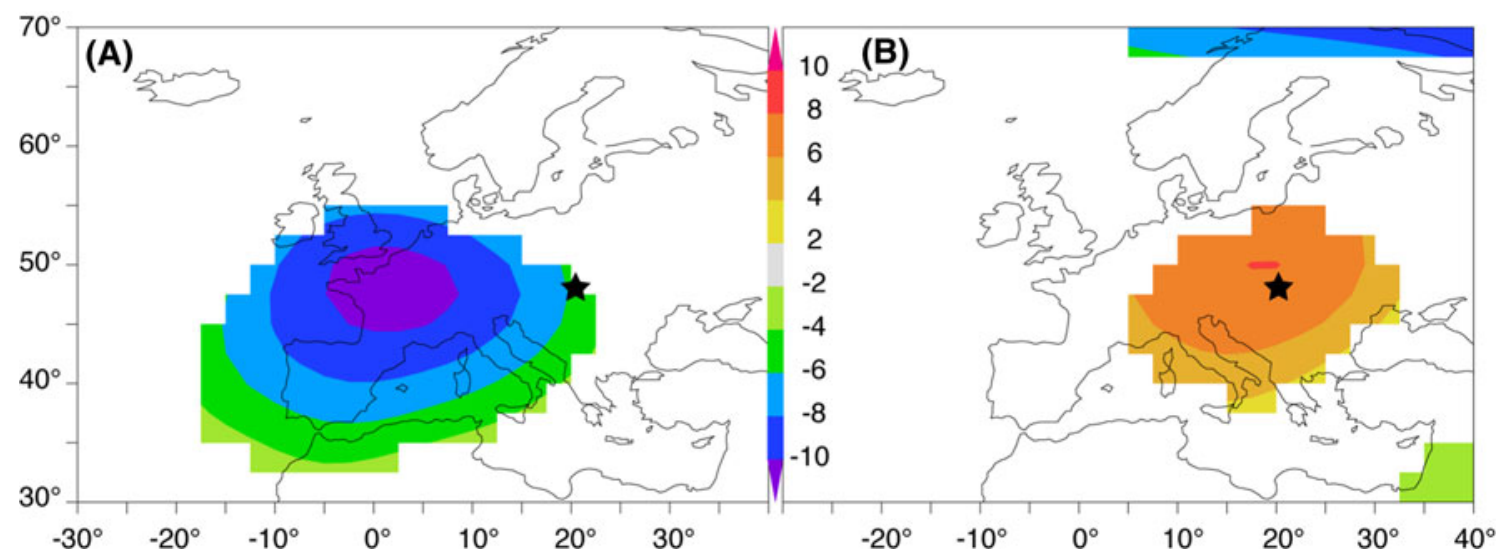

Fig. 6 Composite $500 \mathrm{hPa}$ geopotential height (gpm) for a the 26 wettest and b the 26 driest summers (1744-1999) of the Slovakian JJA scPDSI reconstruction (black star)

Slovakia are, again associated with (1) the Genoa cyclone, (2) van Bebber ( $\mathrm{Vb}$ ) tracks of cyclones originating from the Mediterranean, (3) cyclones located in small distance north-east or east of Slovakia with advancing retrograde warm fronts, and (4) troughs with passing waved cold fronts on their frontal side over Slovakia (Brázdil and Štekl 1986). The analysis of heavy wet spells over Slovakia during 1988-2002 revealed slow moving lows in the $500 \mathrm{hPa}$ level with related occluded fronts to be most responsible (Drinka 2005). Interestingly, these lows were not found at sea-level pressure, which was characterized by an eastern trough spread over Central Europe or a weak cyclone. Precipitation in northwestern and northern Slovakia is primarily triggered by westerly zonal circulation, while precipitation over the remaining $75 \%$ of the Slovak territory is mainly driven by southerly meridional circulation (Lapin and Faško 1996; Lapin and Pišútová 1998). In contrast, low precipitation totals are related to closed (in many cases blocking) anticyclones or ridges of high pressure. During such dry episodes, the most important regime is characterized by relatively dry airflow or concerns the central part of the anticyclone with air subsidence (Brázdil and Štekl 1986).

The herein described synoptic patterns that are mainly responsible for Slovakian summer drought variability also affect tree growth in this region, and can be linked with atmospheric circulation dynamics over the greater European/North Atlantic sector (Raible et al. 2006). We assume the Polish classification by Niedźwiedź (see Lapin and Faško 1996; Lapin and Pišútová 1998) and a classification of the Czech Hydrometeorological Institute (Brádka et al. 1961) to be most appropriate for comparison between continental-scale circulation dynamics and the herein obtained regional-scale results. The latter started in 1946, has been continually updated (Team of authors 1967), and now includes 28 weather types (Řezníčková et al. 2007). Analyses of extremely wet and dry months in Slovakia from 1949 to 1980 elucidated wet summer conditions to be triggered by a frequency-rise of cyclonic situations (predominantly type $\mathrm{C}$-central cyclone), as well as a decreased occurrence of anticyclonic situations (Brázdil and Štekl 1986). On the other hand, dry summers were associated with an amplified frequency of anticyclonic situations (NEanorth-eastern anticyclonic, A-central anticyclone, Wawestern anticyclonic), as well as the reduced occurrence of cyclonic types (mainly NEc-north-eastern cyclonic).

\section{Discussion}

\subsection{Central European perspective}

Comparison between the new Slovakian drought reconstruction and nine annually resolved spring/summer precipitation records from Central Europe is summarized in Fig. 7. Note that two slightly different versions of tree ringbased reconstructions exist for the Vienna Basin (Wimmer, personal communication) and the Bavarian Forest (Wilson et al. 2005). While for the Vienna Basin, two related chronologies were used to either reconstruct shorter (JuneAugust; WMS) or longer (April-August; WML) periods of summer precipitation, different chronologies after composite RCS $(W L R)$ or individual spline $(W L S)$ detrending were used to assess more or less lower frequency MarchAugust precipitation variability, respectively. All other reconstructions also reflect precipitation totals of some seasonal window between March and August, including March-July $(B R A)$, April-June $(O B H)$, and June-August (remaining five records). In contrast, only TST reflects June-August drought fluctuations. While most records represent local- to regional-scales, the combined records from Germany and Switzerland (GLA and PFI) are probably representative for larger areas (see Fig. 5 for locations). Three precipitation reconstructions (GLA, PAU, 


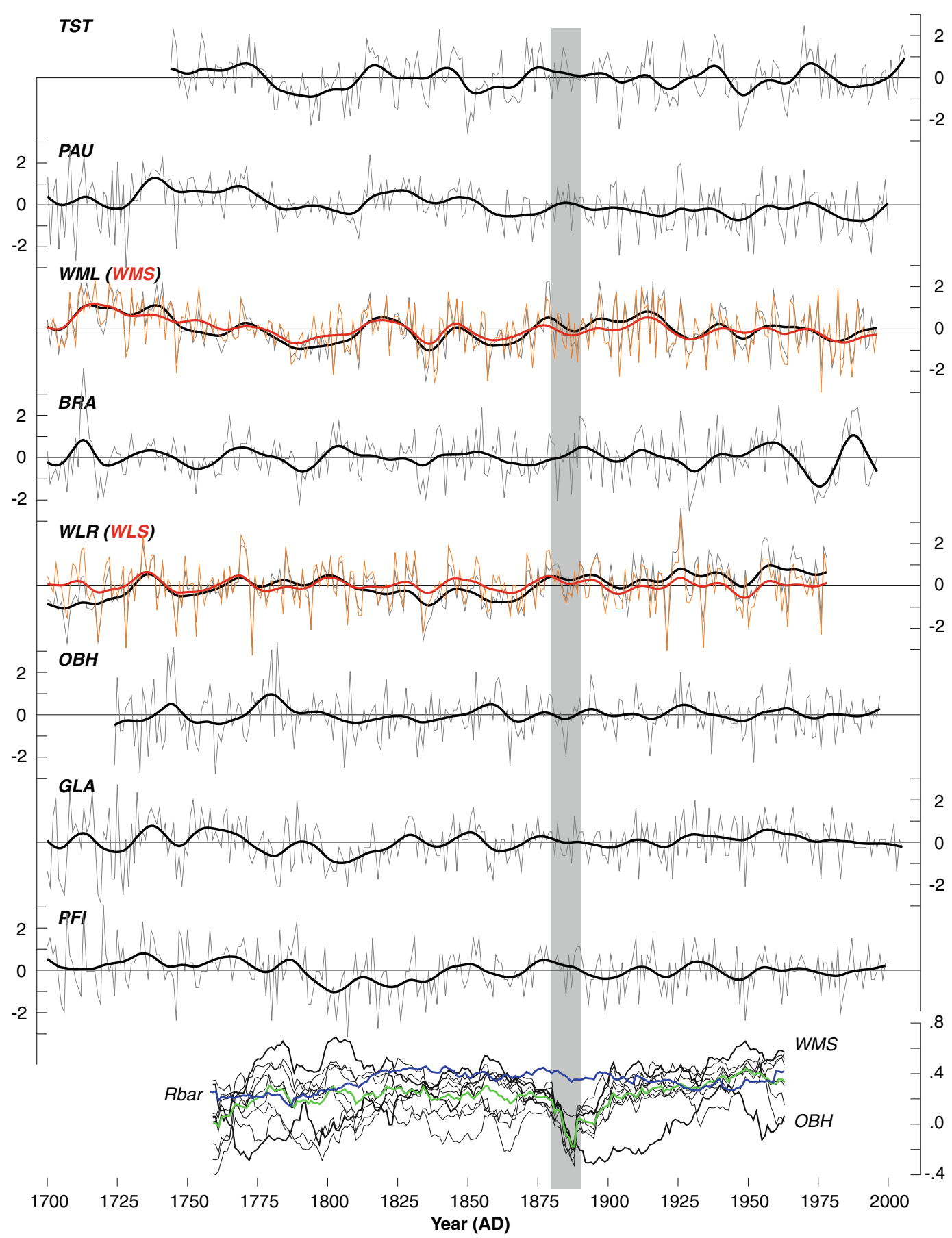

Fig. 7 Fluctuation of Central European hydro-climatic records scaled to have a mean of zero and variance of one over 1700 to present, with the bold lines being 20 year low-pass filters, and the grey shading indicating the $1880 \mathrm{~s}$ that are characterized by reduced coherency between this study and the other records. Bottom part indicates

$P F I)$ are combined with long instrumental station measurements reaching back to the early/mid eighteenth century, positively affecting their correlations with gridded climate data (Table 3). Lag-1 autocorrelations of the timeseries range from 0.1 (GLA, PFI) to 0.45 (TST).
31 year moving correlations (1744-1978) between this study (TST) and the nine hydro-climatic records used for comparison (green line represents their mean). Inter-series correlation (Rbar) of the nine hydro-climatic records computed over 31 year moving windows excluding the new Slovakian record (blue line)

Mean correlation between the ten hydro-climatic records is 0.36 , decreasing to $0.19-0.33$ after $10-50$ year low-pass filtering (1744-1978). Lowest correlation of 0.05 is found between $O B H$ and $P F I$, whereas highest correlation of 0.86 is found between $W L S$ and $W L R$ (both using the same data). 
Table 3 Central European hydro-climatic series used in this study. Lag-1 indicates 1st order autocorrelation (1744-1978). Correlations were computed against the JJA mean of the nearest $0.5^{\circ}$ Climatic Research Unit (CRU) grid box (1901-1978). Stars denote reconstructions that include instrumental data. Average correlation of the seven JJA precipitation grid boxes is 0.56 ranging from 0.31 (PFI/ $W M S)$ to $0.85(B R A / W M S)$. Average correlation of the seven JJA scPDSI grid boxes is 0.55 ranging from 0.14 (TST/GLA) to 0.77 (BRA/ $W M S)$

\begin{tabular}{|c|c|c|c|c|c|c|c|}
\hline \multicolumn{6}{|c|}{ General information } & \multicolumn{2}{|c|}{ Correlation } \\
\hline Code & Proxy & Region & Signal/season & Lag-1 & Source & Precip. & PDSI \\
\hline$T S T$ & TRW & Western Carpathian & PDSI/JJA & 0.45 & This study & 0.41 & 0.59 \\
\hline$P A U$ & Multi-proxy & Western Carpathian & Precip./JJA & 0.22 & Pauling et al. 2006 & $0.86 \star$ & 0.56 \\
\hline$W M S$ & TRW & Vienna Basin & Precip./JJA & 0.30 & Wimmer (pc) & 0.79 & 0.53 \\
\hline$W M L$ & TRW & Vienna Basin & Precip./AMJJA & 0.30 & Wimmer (pc) & 0.68 & 0.65 \\
\hline$B R A$ & TRW & Southern Moravia & Precip./MAMJJ & 0.25 & Brázdil et al. 2002 & 0.20 & 0.42 \\
\hline$W L S$ & TRW_std & Bavarian Forest & Precip./MAMJJA & 0.17 & Wilson et al. 2005 & 0.43 & 0.55 \\
\hline$W L R$ & TRW_rcs & Bavarian Forest & Precip./MAMJJA & 0.41 & Wilson et al. 2005 & 0.42 & 0.57 \\
\hline$O B H$ & TRW & Inn Valley/Austrian Alps & Precip./AMJ & 0.09 & Oberhuber and Kofler 2002 & 0.05 & 0.15 \\
\hline$G L A$ & Documentary & Germany & Precip./JJA & 0.10 & Glaser 2008 & $0.65 \star$ & 0.39 \\
\hline$P F I$ & Documentary & Switzerland & Precip./JJA & 0.09 & Pfister 1999 & $0.86 \star$ & 0.55 \\
\hline
\end{tabular}

Bold values indicate $p<0.01$

Assessment of the individual time-series should, however, consider their different seasonal representations (Table 3). Correlations with JJA precipitation of the nearest grid-box and computed over the common 1901-1978 period (Table 3), vary from $0.05(O B H)$ to $0.86(P A U, P F I)$. Correlations with JJA scPDSI range from $0.15(O B H)$ to $0.65(W M L)$. Interestingly, in some cases, the considered reconstructions reflect summer drought better than precipitation totals as originally claimed. This might be attributed to the nature of the PDSI metric averaging out meteorological differences across time and space, and integrating different aspects of climate, that all affect tree growth, with the later likely being the key driver. Relatively low correlations between the TRW-based MAMJJ precipitation reconstruction for southern Moravia $(B R A)$ and the corresponding JJA gridded precipitation data are most likely related to the utilization of a different target seasonality (Table 3), and the fact that the proxy data contain more uncertainty from the 1960s onwards (Brázdil et al. 2002). However, we believe that choosing one target season more or less best fitting to each individual proxy record, yields most comparable results.

Moving 31 year correlations between this study and the nine Central European spring/summer precipitation reconstructions show reasonable coherency from 1775 to 1875 and again during the twentieth century (Fig. 7). Highest (lowest) agreement is found with WML $(O B H)$. Interestingly, the relationship of the new Slovakian scPDSI record with the other nine Central European proxies collapses in the 1880s. Rather stable inter-chronology correlations between the nine hydro-climatic estimates-the mean value is 0.33 (17441978)_provides further evidence that this loss of coherency is mainly restricted to the Slovakian data (Fig. 7). Decreasing coherency (correlations $<0.2$ ) is also seen prior to $\sim 1820$, most likely due to an overall decline in sample replication (including a dropout of instrumental station data).

Common indicators for Central European-wide drought spells exist for the 1860s and the 1940s. All records except three $(O B H, W L S$ and $W L R)$, denote decreasing values from initially wet conditions $\sim 1750$ towards a drier period centered $\sim 1800$. Caution prior to the nineteenth century is though advised, as an increase in standard deviation back in time is at least significant for three records $(O B H, G L A$, $P A U)$ (Fig. 8a). Such variance changes can be artificial in nature and complicate the detection of extreme events (Frank et al. 2007b). Affects on the overall amplitude range and power spectrum of the time-series must be considered as well. A common feature and most likely independent of any systematic disturbance, is a century long variance depression from $\sim 1775$ to 1875 surrounded by slightly increasing standard deviations from 1775 back in time, and from 1875 until present.

Global wavelet power spectra (Torrence and Compo 1998) of all ten hydro-climatic records provide helpful information about their spectral 'color' behavior (Fig. 8b). A significant power cycle at $\sim 15$ years is evident for TST, OBH, and the $W L S$ and $W L R$ time-series. Significant power at $\sim 65$ years is found in four records (TST, PAU, WMS, WML).

\subsection{Remaining uncertainties}

When using living trees only, a constant decrease in sample size lowers the mean chronology's signal-to-noise ratio, and may also result in artificial variance increases back in time (Frank et al. 2007b). Utilization of samples from living trees further results in an uneven distribution of 


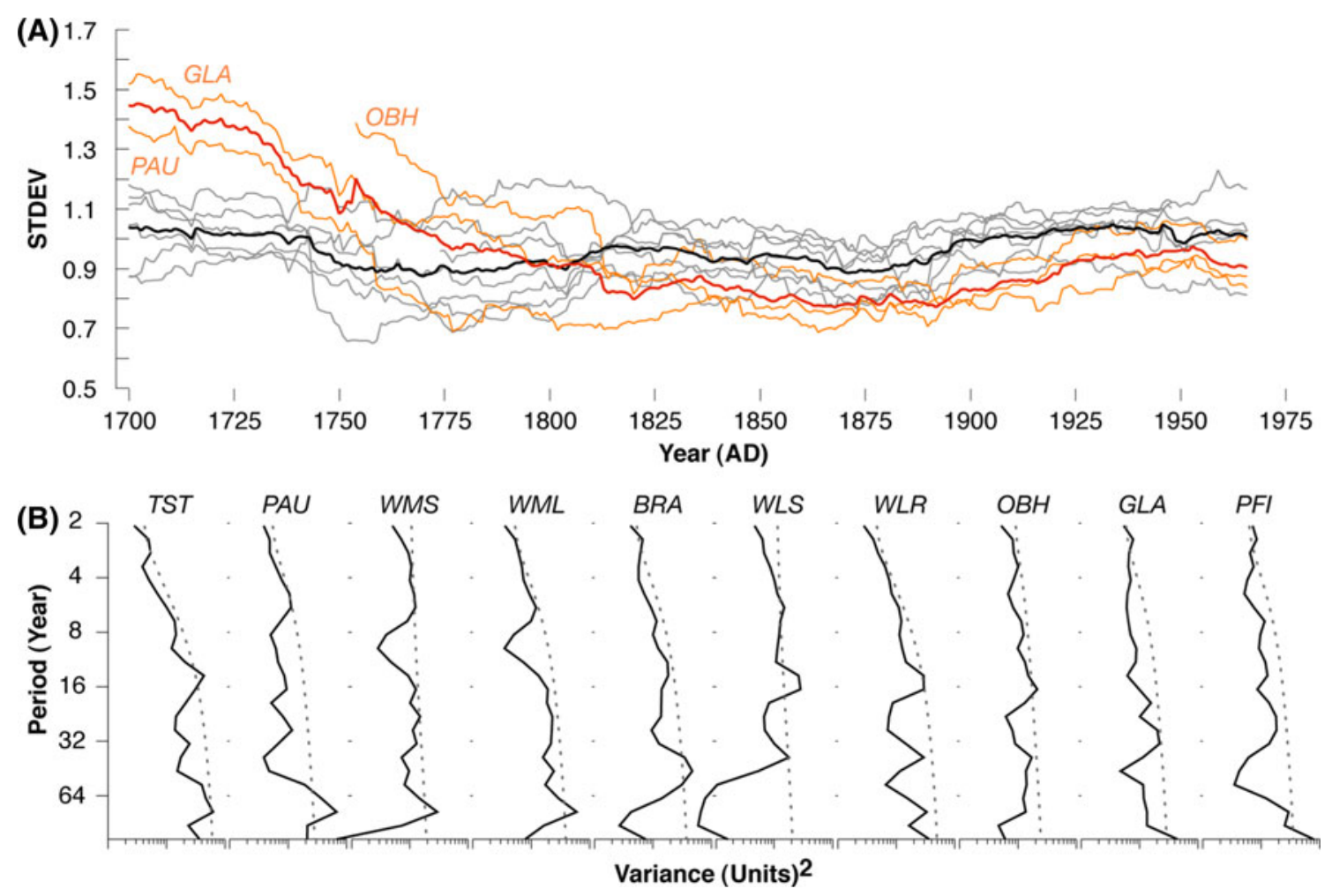

Fig. 8 a Standard deviations of the individual (standardized) Central European hydro-climatic records (as introduced in Table 3, Fig. 7) calculated over 61 year moving windows stress increasing variability back in time. Red and black curves are simple averages of the three orange and seven grey lines, respectively. b Power spectra (Morlet

juvenile and mature growth levels - annual growth rates of the same cambial age are not randomly distributed over time (see Fig. 1 for details). We here refer to Esper et al. (2008) for methodological details on age-dependent climate sensitivity. Commonly applied individual detrending methods are per se limited in the preservation of low-frequency information, at least above the mean segment length (Cook et al. 1995). Such effects become even more complicated when mean segment length changes over time. As for this study, a slight decrease in series length appears along the chronology, the preservation of longer-term drought variability may possibly be impacted.

Various homogenization procedures applied to instrumental station data are also prone to error, and can systematically bias inferred relationships with tree growth (Frank et al. 2007a). Methodological issues related to the aggregation of gridded global datasets might cause additional limitations in reflecting the full range of long-term climate change (Mitchell and Jones 2005).

Due to the interaction of several climatic drivers $(\mathrm{Ne}-$ mani et al. 2003), and a complex plant physiology (Kozlowski and Pallardy 1997), the discrimination of growth responses amongst temperate forests to a single controlling parameter often fails (Friedrichs et al. 2009). Further
6.0/6 global wavelets) of the Central-European hydro-climatic records computed over the 1744-1978 period stress decreasing variability at lower frequencies. Dashed lines are 10\% significance levels using red-noise (autoregressive lag-1) background spectra

complication stems from anthropogenic pollution effects during the second half of the twentieth century (e.g., Brázdil et al. 2002; Wilson et al. 2005), and superimposed changes in cloud cover (Warren et al. 2007).

As an experiment, this study was compared with the existing (nearby) summer temperature reconstruction from the Tatra Mountains (Büntgen et al. 2007). Correlation between the two records is -0.17 , and change to -0.33 after 10 year smoothing. This relationship clearly depicts the inverse relationship between high- and low-elevation tree growth, mainly being positively stimulated by warm (highpressure) and wet (low-pressure) summers, respectively. Since opposing growth fluctuations are most pronounced on decadal time-scales, they further underscore augmented proxy uncertainty on inter-annual and again multi-decadal wavelength (e.g., Frank et al. 2007a); those frequency domains during which a lower signal-to-noise ratio is a characteristic feature for TRW-based climate reconstructions.

\section{Conclusions}

Based on a collection of 86 TRW series from Slovakia, regional summer drought variability was reconstructed 
back to 1744 . Summer droughts were most severe in 1794 , 1850, 1904, and 1947, with decadal fluctuations being superimposed. Documentary evidence on the timing and intensity of most severe extreme years across the Carpathian basin and surroundings is in agreement with our findings, and thus allowed a detailed understanding of prevailing climatic patterns. Synoptic interpretation of summer droughts over the past 250 years demonstrates the influence of Central European high-pressure systems. In contrast, low pressure over Western Europe triggered wet summer conditions over the past centuries. Comparison between this study and nine existing Central European spring/summer precipitation reconstructions describes reasonable coherency from 1775 to 1875 and again during the twentieth century. Together with evidence obtained from instrumentally derived scPDSI data, our compilation of hydro-climatic estimates reveals no indication of a centurylong drying trend or associated reductions in Central European forest productivity.

Acknowledgments We are grateful to R. Glaser, W. Oberhuber, A. Pauling, C. Pfister, R. Wimmer, and R. Wilson for making their original reconstructions available. P. Faško provided average precipitation series and A. Kiss documentary data for Slovakia. A. Verstege measured tree-ring width, R. J. Kaczka supported fieldwork, J. Luterbacher and R. J. S. Wilson contributed via discussion. Supported by the SNF project NCCR-climate (Extract) and the EC project MILLENNIUM (\#017008).

\section{References}

Bartholy J, Pongrácz R (2007) Regional analysis of extreme temperature and precipitation indices for the Carpathian basin from 1946 to 2001. Glob Planet Change 57:83-95. doi: 10.1016/j.gloplacha.2006.11.002

Bartholy J, Pongrácz R, Molnár Z (2004) Classification and analysis of past climate information based on historic documentary sources for the Carpathian Basin. Int J Climatol 24:1759-1776. doi:10.1002/joc. 1106

Brázdil R, Kiss A (2001) Daily weather observations at Košice, Slovakia, in the period 1677-1681. Meteorol Cas 4:3-14

Brázdil R, Štekl J (1986) Cirkulační procesy a atmosférické srážky v ČSSR (Circulation processes and atmospheric precipitation in the C.S.S.R.). Univerzita J. E. Purkyně, Brno

Brádka J, Dřevikovský A, Gregor Z, Kolesár J (1961) Počasí na území Čech a Moravy v typických povětrnostních situacích (Weather on the territory of Bohemia and Moravia in typical weather situations). Hydrometeorologický ústav, Praha

Brázdil R, Štěpánková P, Kyncl T, Kyncl J (2002) Fir tree-ring reconstruction of March-July precipitation in southern Moravia (Czech Republic), 1376-1996. Clim Res 20:223-239. doi: $10.3354 / \mathrm{cr} 020223$

Brázdil R, Pfister C, Wanner H, von Storch H, Luterbacher J (2005) Historical climatology in Europe-state of the art. Clim Change 70:363-430. doi:10.1007/s10584-005-5924-1

Brázdil R, Kiss A, Luterbacher J, Valášek H (2008a) Weather patterns in eastern Slovakia 1717-1730, based on records from the Breslau meteorological network. Int J Climatol 28:1639-1651. doi:10.1002/joc. 1667
Brázdil R, Trnka M, Dobrovolný P, Chromá K, Hlavinka P, Žalud Z (2008b) Variability of droughts in the Czech Republic, 18812006. Theor Appl Climatol. doi:10.1007/s00704-008-0065-x

Büntgen U, Frank DC, Kaczka RJ, Verstege A, Zwijacz-Kozica T, Esper J (2007) Growth/climate response of a multi-species treering network in the Western Carpathian Tatra Mountains, Poland and Slovakia. Tree Physiol 27:689-702

Büntgen U, Frank DC, Wilson R, Carrer M, Urbinati C, Esper J (2008) Testing for tree-ring divergence in the European Alps. Glob Change Biol 14:2443-2453. doi:10.1111/j.1365-2486. 2008.01640.x

Casty C, Wanner H, Luterbacher J, Esper J, Böhm R (2005) Temperature and precipitation variability in the European Alps since 1500. Int J Climatol 25:1855-1880. doi:10.1002/joc.1216

Cebulak E, Faško P, Lapin M, Štastný P (2000) Extreme precipitation events in the Western Carpathians. In: Prace Geograficzne, vol 108, Instytut Geografii, UJ, pp 117-124

Cook ER (1985) A time series analysis approach to tree-ring standardization. PhD Thesis, University of Arizona, p 171

Cook ER, Peters K (1981) The smoothing spline: a new approach to standardizing forest interior tree-ring width series for dendroclimatic studies. Tree-Ring Bull 41:45-53

Cook ER, Briffa KR, Jones PD (1994) Spatial regression methods in dendroclimatology: a review and comparison of two techniques. Int J Climatol 14:379-402. doi:10.1002/joc.3370140404

Cook ER, Briffa KR, Meko DM, Graybill DA, Funkhouser G (1995) The 'segment length curse' in long tree-ring chronology development for palaeoclimatic studies. Holocene 5:229-237. doi: $10.1177 / 095968369500500211$

Dobrovolný P, Brázdil R, Valášek H, Kotyza O, Macková J, Halićková M (2009) A standard paleoclimatological approach to temperature reconstruction in historical climatology: an example from the Czech Republic, A.D. 1718-2007. Int J Climatol (in press)

Drinka R (2005) Synoptic causes of wet-spell occurrence in Slovakia during 1988-2002. Meteorol Cas 8:193-198

Durbin J, Watson GS (1951) Testing for serial correlation in least squares regression. Biometrika 38:159-178

Esper J, Niederer R, Bebi P, Frank DC (2008) Climate signal age effects: evidence from young and old trees in the Swiss Engadin. For Ecol Manage 255:3783-3789

Faško P, Lapin M, Sekáčová Z, Štastný P (2003) Extraordinary climatic anomaly in 2003. Meteorol Cas 6:3-7

Frank D, Büntgen U, Böhm R, Maugeri M, Esper J (2007a) Warmer early instrumental measurements versus colder reconstructed temperatures: shooting at a moving target. Q Sci Rev 26:32983310. doi:10.1016/j.quascirev.2007.08.002

Frank D, Esper J, Cook E (2007b) Adjustment for proxy number and coherence in a large-scale temperature reconstruction. Geophys Res Lett 34. doi: 10.1029/2007GL030571

Friedrichs D, Büntgen U, Esper J, Frank D, Neuwirth B, Löffler J (2009) Complex climate controls on 20th century oak growth in Central-West Germany. Tree Physiol 29:39-51. doi:10.1093/ treephys/tpn003

Fritts HC (1976) Tree rings and climate. Academic Press, London, p 567

Glaser R (2008) Klimageschichte Mitteleuropas. 1200 Jahre Wetter, Klima, Katastrophen. Wissenschaftliche Buchgesellschaft, Darmstadt, p 264

Huntington TG (2006) Evidence for intensification of the global water cycle: review and synthesis. J Hydrol (Amst) 319:83-95. doi: 10.1016/j.jhydrol.2005.07.003

IPCC (2007) Climate change 2007: the physical science basis. Contribution of working group I to the fourth assessment report of the IPCC. Cambridge University Press, Cambridge

Klementová E, Litschmann T (2002) Detekcia výskytu sucha v Hurbanove (Detection of drought occurrence at Hurbanovo). 
In: Antal J. Očakávané globálne zmeny klímy a ich možný dopad na vodný režim, poľné a lesné hospodárstvo. Slovenská akadémia pôdohospodárských vied, Nitra, pp 45-50

Klementová E, Litschmann T (2004) The agro-climatic drought in Slovakia in 2003. Meteorol Cas 7:11-16

Kozlowski TT, Pallardy SG (1997) Growth control in woody plants. Academic Press, San Diego

Lapin M, Faško P (1996) Úhrny zrážok na Slovensku a zmeny atmosférickej cirkulácie v období 1874-1993 (precipitation totals in Slovakia and changes in atmospheric circulation in the 1874-1993 period). Meteorol Zpr 49:1-11

Lapin M, Faško P (1998) Change of precipitation variability in Slovakia in the 1881-1997 period. In: Proceedings of the 25th international conference on Alpine meteorology, Torino, pp 126-131

Lapin M, Pišútová Z (1998) Changes of cyclonicity, air pressure and precipitation totals in the 1901-1995 period. Meteorol Cas 1:15-22

Litschmann T, Klementová E (2004) Using Palmer Drought Severity Index to assess drought in the territory of Slovakia. Meteorol Cas 7:67-72

Luterbacher J, Xoplaki E, Dietrich D, Rickli R, Jacobeit J, Beck C, Gyalistras D, Schmutz C, Wanner H (2002) Reconstruction of sea level pressure fields over the Eastern North Atlantic and Europe back to 1500 . Clim Dyn 18:545-561

Mann ME, Lees JM (1996) Robust estimation of background noise and single detection in climatic time series. Clim Change 33:409-445. doi:10.1007/BF00142586

Mitchell TD, Jones PD (2005) An improved method of constructing a database of monthly climate observations and associated highresolution grids. Int J Climatol 25:693-712. doi:10.1002/joc.1181

Nemani RR, Keeling CD, Hashimoto H, Jolly WM, Piper SC, Tucker CJ, Myneni RB, Running SB (2003) Climate-driven increases in global terrestrial net primary production from 1982 to 1999. Science 300:1560-1563. doi:10.1126/science. 1082750

Oberhuber W, Kofler W (2002) Dendroclimatological spring rainfall reconstruction for an inner Alpine dry valley. Theor Appl Climatol 71:97-106. doi:10.1007/s704-002-8210-8

Pauling A, Paeth H (2007) On the variability of return periods of European winter precipitation extremes over the last three centuries. Clim Past 3:65-76

Pauling A, Luterbacher J, Casty C, Wanner H (2006) 500 years of gridded high resolution precipitation reconstructions over Europe and the connection to large-scale circulation. Clim Dyn 26:387-405. doi:10.1007/s00382-005-0090-8

Pfister C (1999) Wetternachhersage. 500 Jahre Klimavariationen und Naturkatastrophen 1496-1995. Haupt, Bern Stuttgart Wien

Rácz L (1999) Climate history of Hungary since 16th century: past, present and future. Centre for Regional Studies of Hungarian Academy of Sciences, Pécs, p 158
Raible CC, Casty C, Luterbacher J, Pauling A, Esper J, Frank DC, Büntgen U, Roesch AC, Tschuck P, Wild M, Vidale PL, Schär C, Wanner H (2006) Climate variability: observations, reconstructions, and model simulations for the Atlantic-European and Alpine region from 1500-2100 AD. Clim Change 79:9-29. doi: 10.1007/s10584-006-9061-2

Réthly A (1970) Időjárási események és elemi csapások Magyarországon 1701-1800 (weather events and natural extremes in Hungary, 1701-1800). Akadémiai Kiadó, Budapest

Réthly A, Simon A (1998-1999): Időjárási események és elemi csapások Magyarországon 1801-1900 (meteorological events and natural disasters in Hungary between 1801-1900), vol I-II. Országos Meteorológiai Szolgálat, Budapest

Řezníčková L, Brázdil R, Tolasz R (2007) Meteorological singularities in the Czech Republic in the period 1961-2002. Theor Appl Climatol 88:179-192. doi:10.1007/s00704-006-0253-5

Šamaj F, Valovič Š (1982) Priestorové úhrny zrážok na Slovensku (1881-1980) (Areal precipitation totals over Slovakia, 18811980). Meteorol Zpr 35:108-112

Schär C, Vidale PL, Lüthi D, Frei C, Häberli C, Liniger MA, Appenzeller C (2004) The role of increasing temperature variability in European summer heatwaves. Nature 427:332336. doi: $10.1038 /$ nature 02300

Seager R, Graham N, Herweijer C, Gordon AL, Kushnir Y, Cook E (2007) Blueprints for medieval hydroclimate. Q Sci Rev 26:2322-2336. doi:10.1016/j.quascirev.2007.04.020

Strömmer E (2003) Klima-Geschichte. Methoden der Rekonstruktion und historische Perspektive Ostösterreich 1700 bis 1830. Franz Deuticke, Wien

Team of authors (1967) Katalog povětrnostních situací pro území ČSSR (Catalogue of weather situations for the C.S.S.R. territory). Hydrometeorologický ústav, Praha

Torrence C, Compo GP (1998) A practical guide to wavelet analysis. Bull Am Meteorol Soc 79:61-78. doi:10.1175/1520-0477(1998) 079<0061:APGTWA $>2.0 . \mathrm{CO} ; 2$

van der Schrier G, Briffa KR, Jones PD, Osborn TJ (2006) Summer moisture variability across Europe. J Clim 19:2818-2834. doi: 10.1175/JCLI3734.1

Warren SG, Eastman RM, Hahn CJ (2007) A survey of changes in cloud cover and cloud types over land from surface observations, 1971-96. J Clim 20:717-738. doi:10.1175/JCLI4031.1

Wigley TML, Briffa KR, Jones PD (1984) On the average of value of correlated time series, with applications in dendroclimatology and hydrometeorology. J Clim Appl Meteorol 23:201-213. doi: 10.1175/1520-0450(1984)023<0201:OTAVOC $>2.0 . C O ; 2$

Wilson RJS, Luckman BH, Esper J (2005) A 500 year dendroclimatic reconstruction of spring-summer precipitation from the lower Bavarian Forest region, Germany. Int J Climatol 25:611-630. doi: $10.1002 /$ joc. 1150 